\title{
Co-Production of Vegetables and Electricity in Agricultural Greenhouses in Crete, Greece. Is it Feasible?
}

\author{
John Vourdoubas \\ Mediterranean Agronomic Institute of Chania \\ 73100, Chania, Crete, Greece \\ Tel: +30-28210-35020
}

\begin{abstract}
Use of solar photovoltaics in agricultural greenhouses could result in co-production of food products and electricity. The technical and economic feasibility of using semi-transparent solar panels on the rooftop of greenhouses in Crete, Greece has been investigated. The impacts of their use on the plant's growth have been mentioned and a preliminary study for a 10 ha greenhouse located in Crete, Greece has been implemented. Semi-transparent solar panels covering $15 \%$ of the rooftop surface could generate $16.8 \mathrm{KWh}$ per $\mathrm{m}^{2}$ of the greenhouse's surface while their installation cost is estimated at $24 \mathrm{E} / \mathrm{m}^{2}$. The annual decrease of $\mathrm{CO}_{2}$ emissions due to their use is at $10.08 \mathrm{kgCO} / \mathrm{m}^{2}$ while the levelized cost of the generated electricity is estimated at $0.082 \mathrm{E} / \mathrm{KWh}$. It is concluded that the use of semi-transparent solar panels on the rooftop of greenhouses in Crete, Greece would result in economic and environmental benefits for the farmer.
\end{abstract}

Keywords: CHP, Crete-Greece, energy cooperatives, energy generation, greenhouses, opaque photovoltaics, semitransparent, solar energy

\section{Introduction}

Promoting sustainability in agriculture is necessary for mitigation of climate change and in providing the required foodstuff for an increasing global population. Use of renewable energies in agriculture and in food production systems will assist in the reduction of carbon emissions as well as in fossil fuels use. Solar photovoltaics (solar-PVs) can be used in modern greenhouses generating electricity covering part or all of their energy needs and selling the surplus into the grid. Current advances in solar energy technologies allow the use of semi-transparent solar-PVs placed on the rooftop of modern greenhouses for electricity generation provided that they will not affect the growth and the yield of the cultivated crops. This is attractive in areas with rich solar energy resources like the Mediterranean region. Therefore modern agricultural greenhouses could be transformed in hybrid energy and food production systems which could simultaneously co-generate energy and food products offering economic and environmental benefits to their owners. A farmer simultaneously producing and consuming electricity will become "pro-cumer". Solar-PV greenhouses will allow farmers to have an additional economic income due to the generated electricity. However the impacts of solar-PVs, placed on the rooftop of greenhouses, on the incoming solar irradiance as well as on the indoor microclimate should be carefully studied in order to avoid lower and low quality crop yields.

\section{Literature survey}

\subsection{Energy requirements in agricultural greenhouses}

Canacki et al, 2006 have analyzed the energy use pattern in greenhouse vegetable crops located in Antalya, Turkey which is the heart of the country's greenhouse industry. The authors estimated that the greenhouses' operational energy requirements, for tomato, cucumber, pepper and eggplant crops, vary between $6.64 \mathrm{KWh} / \mathrm{m}^{2}$ to $7.79 \mathrm{KWh} / \mathrm{m}^{2}$. Hassanian et al, $\mathbf{2 0 1 6}$ have reviewed the advanced applications of solar energy in agricultural greenhouses, including solar-PV energy. The authors stated that annual electricity consumption used for heating, cooling, lighting and operation of various devices in different countries varies significantly in the range of $2 \mathrm{KWh} / \mathrm{m}^{2}$ in Mediterranean countries to over $500 \mathrm{KWh} / \mathrm{m}^{2}$ in Scandinavian countries. They also mentioned that the annual electricity consumption in Greek greenhouses was estimated at $20 \mathrm{KWh} / \mathrm{m}^{2}$. Marucci et al, 2013 have estimated the energy surplus for various crops which could be used to generate electricity in 'Mediterranean type greenhouses" located in the Lazio region, central Italy. The authors stated that for an annual tomato crop the daily energy surplus during May to August was between $2.2 \mathrm{KWh} / \mathrm{m}^{2}$ to $3 \mathrm{KWh} / \mathrm{m}^{2}$ while in greenhouses used for eggplant, it was higher at $3.6-4.2 \mathrm{KWh} / \mathrm{m}^{2}$. Kagarakis, 1987 has estimated the average annual solar irradiance in various towns in Crete, Greece in a tilt angle of $30^{\circ}$ at $1,755 \mathrm{KWh} / \mathrm{m}^{2}$. 


\subsection{Use of solar-PVs in greenhouses}

Colantoni et al, 2018 have studied the solar radiation distribution inside a greenhouse, equipped with a mobile solarPV system, used for flower cultivation. The authors stated that the solar-PV system was covering $20 \%$ of its roof surface. They also mentioned that the mobile solar-PV plant should: a) be able to generate electricity offering an additional income, b) ensure that the indoor solar irradiance was satisfactory for plant growth, and c) the indoor microclimate conditions were not altered. Moretti et al, 2019 have investigated the possibility of using a mobile solarPV system, with variable shading, in a greenhouse in order to optimize agricultural and energy production. The authors stated that by moving the solar-PV system, the greenhouse's shading was varied. This allows the regulation of the indoor solar irradiance while plant growth was not disrupted. Xue, 2017 has studied the economic performance of photovoltaic greenhouses. The author mentioned that PV-greenhouses consist of a new mode of distributed solar-PV power generation combined with agricultural production in greenhouses. He stated that the profitability of PVgreenhouses depend on many parameters while he suggested, in this type of greenhouse, to plant crops with high economic impact. Castellano, 2014 has evaluated the influence of shading solar-PV systems on agricultural greenhouses. The author stated that existing regulations propose that the share of greenhouse roof area covered with opaque panels should be in the range of $25 \%$ to $50 \%$. He also mentioned that shading effect had a linear correlation with the covering ratio. Urena-Sanchez et al, 2012 have investigated the impact of roof-mounted flexible solar panels on greenhouse tomato crops in southeastern Spain. The authors installed solar panels covering $9.8 \%$ of the roof area in two experimental greenhouses comparing tomato growth with a control greenhouse. They found that the solar panel installation did not affect the yield and the price of the tomato produced. Kadowaki et al, 2012 have studied the impact of solar-PV panels mounted on the roof of two greenhouses on the productivity of cultivated Welsh onions. The authors mentioned that the solar-PV panels were covering $12.9 \%$ of the roof-top surface. They found that the crop's productivity of the solar-PV greenhouses was lower compared with the control greenhouse. Cossu et al, 2017 have studied the effects of the photovoltaic roofs on greenhouse microclimate. The authors recorded the values of solar radiation and the temperature inside a greenhouse with 50\% roof coverage with poly-crystalline silicon PV panels. They found that the average annual temperature inside the $\mathrm{PV}$-greenhouse was $3^{\circ} \mathrm{C}$ higher than the ambient temperature while the solar irradiance in a conventional greenhouse with a plastic roof was $305 \%$ higher than in the PV-greenhouse. Cossu et al, 2014 have investigated the distribution of solar radiation inside a greenhouse with solar-PV roof. The authors implemented experiments in a greenhouse with tomato crop which had covered $50 \%$ of its roof with solar-PV modulus. They found that solar radiation inside the greenhouse has decreased annually by $64 \%$ while the crop's yield was also reduced. However the farmer had an additional income due to electricity generation. Yano et al, 2009 have investigated the energy generation by amorphous PV modulus, with nominal power at $24 \mathrm{~W}_{\mathrm{p}}$ and efficiency at $7 \%$, mounted inside the roof of a greenhouse. The size of the modulus was $832 \mathrm{~mm} \mathrm{X} 412 \mathrm{~mm}$. The authors estimated the maximum annual electricity generation at $33.17 \mathrm{KWh}$ while the modulus with lower tilt angle generated more electricity. They also stated that although PV modulus mounted outside the greenhouse roof generated more energy, they are vulnerable to violent weather conditions. Yano et al, 2014 have studied the use of semi-transparent PV modules for application on greenhouse roofs. The authors covered $39 \%$ of the greenhouse roof with two different semitransparent cells having energy efficiencies at $1.6 \%$ and $4.5 \%$ respectively. Their experimentation indicated that these PV-cells are suitable for greenhouse use in high-irradiation areas. Hassanien et al, 2017 have investigated the impacts of greenhouse-integrated semi-transparent PV on indoor microclimate and lettuce growth. The authors used semitransparent mono-crystalline PVs covering $20 \%$ of the roof area of a greenhouse covered with polyethylene used for lettuce production. They found that, due to shading, the indoor solar radiation was decreased by $35-40 \%$ and the indoor temperature by $1-3^{\circ} \mathrm{C}$. However this did not affect the growth and yield of the lettuce plants. Martellota et al, 2017 have compared the performance of different semi-transparent solar-PVs applied in buildings. The authors used different types of semi-transparent amorphous silicon cells with efficiencies in the range of 6-6.6\% in buildings. They stated that their use reduces the solar gains in the building regarding its heating and cooling while they produce electricity covering part of its energy demand. Li et al, 2018 have studied the use of semi-transparent solar-PV modulus, with changing inclination, in greenhouses. The authors estimated the net annual electricity generation of the modulus at 7.8 $\mathrm{KWh} / \mathrm{m}^{2}$. They suggested that the use of these benign energy-generating systems in greenhouses is useful, enabling sunlight level control and providing electricity for covering their energy requirements. Aroca-Delgado et al, 2018 have reviewed the existing literature regarding the use of solar-PV systems for shading crops. The authors mentioned that the use of solar-PV panels for shading crops requires more research for determining the optimum covering area with panels to avoid reduction of agricultural production. Vourdoubas, 2018 has studied the profitability of solar-PV investments in agricultural greenhouses in Greece. The author estimated payback periods between 7.2 and 14.4 years, depending on subsidies obtained, while the net present value of the solar-PV investment was positive. 
He also mentioned that payback periods for solar-PV investments in greenhouses has been reported in the range of 4-25 years while in modern greenhouses located in Crete, achieving indoor climate control, the share of electricity to the annual energy consumption is less than 10\%. Vourdoubas, 2016 investigated the possibility of using semi-transparent PV panels on the rooftops of greenhouses located in Crete, Greece for covering their energy requirements and selling the surplus electricity into the grid. The author estimated that by installing PV panels in greenhouses covering slightly less than $50 \%$ of their rooftop, the generated electricity could cover all their energy needs while the surplus could be sold into the grid, offering an additional income to the farmer.

\subsection{Use of co-generation systems in greenhouses}

Villarroel-Schneider et al, 2019 have investigated the performance of a small-scale biogas based tri-generation plant, at $5 \mathrm{KW}_{\mathrm{el}}$, in a rural area in Bolivia. The authors mentioned that the tri-generation system was generating electricity, hot water and cooling with a heat absorption system covering the energy requirements of a small dairy farm. They stated that although its performance was very satisfactory, more research is required in real conditions. Tataraki et al, 2019 have studied the use of combined cooling, heating and power co-generation systems in greenhouses in Greece. The authors stated that the use of CCHP systems in greenhouses cultivating tomatoes and cucumbers is cost-effective. They mentioned that hybrid energy systems using a gas boiler and a CCHP system, in greenhouses cultivating tomato, achieves a return of investment at 23-28\% in various Greek territories. Renier van der Veen et al, 2015 have implemented a case study on diffusion on CHP technology in Dutch greenhouses. The authors identified five key drivers for the remarkable diffusion of CHP in Dutch greenhouses during 2003-2009. They also stated that promotion of CHP technology was co-evolved from interacting developments in technology, economy, ecology, culture and Institutions. Compernolle et al, 2011 have investigated the economic and environmental impacts of CHP in greenhouses. The authors implemented two case studies in greenhouses with lettuce and tomato crops. They found that in both greenhouses CHP technology was profitable having positive NPVs while $\mathrm{CO}_{2}$ emissions savings varied, between $30 \%$ to $39 \%$, compared to separate heat and electricity generation. A guide for the promotion of CHP technology in agricultural greenhouses has been developed, 2013. A set of eight criteria which could assist local authorities in developing policies promoting CHP technology in greenhouses has been presented. These criteria include: type of greenhouse, type of fuel, CHP capacity, maximum CHP capacity, CHP efficiency, heat storage, emissions and nuisance. Sardella, 2013 has performed an energy analysis of a fuel cell system used in commercial greenhouse applications. The author studied a stationary proton exchange membrane fuel cell using reformed natural gas. He found that a $3 \mathrm{KW}$ fuel cell could cover $25 \%$ of the greenhouse's annual electricity requirements while the cogenerated heat together with the produced heat during NG reform could cover $30 \%$ of its annual heat requirements. Creupelandt et al 2014 have reported on mobilization of EU citizens to invest in sustainable energy. The authors mentioned that RES cooperatives could deliver a significant share of Europe's renewable energy, while by 2050 half of the citizens of European could become energy "procumers". They also stated that RES cooperatives have many things to offer to local authorities which should promote and support them. The advantages and drawbacks due to the use of semi-transparent solar-PVs in greenhouses are presented in Table 1.

Table 1. Advantages and drawbacks due to the use of semi-transparent solar-PVs in agricultural greenhouses

\begin{tabular}{|l|l|}
\hline Advantages & Drawbacks \\
\hline $\begin{array}{l}\text { Electricity generation results in an additional } \\
\text { income. The farmer has revenues from two } \\
\text { different sources. }\end{array}$ & $\begin{array}{l}\text { Reduction of the indoor solar irradiance due } \\
\text { to shading of the solar panels which might } \\
\text { affect the crop's growth and yield }\end{array}$ \\
\hline Reduction of cooling needs in the summer & Increase of heating needs in the winter \\
\hline $\begin{array}{l}\text { Reduction of the greenhouse's carbon footprint } \\
\text { due to energy use }\end{array}$ & $\begin{array}{l}\text { Capital is required for the initial investment in } \\
\text { the solar-PV system }\end{array}$ \\
\hline Increase in the energy autonomy of the farmer & \\
\hline
\end{tabular}

The aims of the current work are:

a) Presentation of the sustainable energy technologies which are currently used and could used in the future for electricity generation in greenhouses,

b) Investigation of the economic and environmental impacts of installing semi-transparent solar-PV panels on the rooftops of agricultural greenhouses in the island of Crete, Greece, and

c) Investigation of the possibility of the creation of RES cooperatives based on installing solar-PV panels in areas with a high concentration of greenhouses in Crete. 
The methodology followed includes: a) estimation of the energy requirements in "Mediterranean-type greenhouses" in Crete, $b$ ) investigation of the available sustainable energy technologies which could be used for electricity generation in greenhouses in Crete, c) economic and environmental assessment due to installation of semi-transparent PV panels, and d) consideration regarding the creation of a RES cooperative among greenhouse owners who could become "procumers", installing PV panels in their greenhouses in Crete.

\section{Energy requirements in agricultural greenhouses in Crete}

Energy requirements in agricultural greenhouses depend on the type of construction, the cultivated crop and the local climate conditions. These differ considerably between "Mediterranean greenhouses" and "Northern European greenhouses". Energy needs for "Mediterranean-type greenhouses" with polyethylene cover cultivating vegetables, which are dominant in Crete, are low in the range of $2-20 \mathrm{KWh} / \mathrm{m}^{2}$, compared with modern "Industrial-type greenhouses", due to the mild climate in the island.

\section{Possibilities for electricity generation in agricultural greenhouses by sustainable energies in Crete}

\subsection{Electricity generation by co-generation of heat and power systems}

Co-generation of heat and power (CHP) systems producing electricity, heat and cooling are currently used in large "industrial greenhouses". Usually the produced heat covers all the heating needs while the co-generated electricity covers the electricity needs and the surplus is sold into the grid. Current legislation in Greece promotes the use of CHP systems in many applications including in greenhouses. Cooling could be provided during the summer, when it is needed, using thermal absorption cooling systems. Natural gas or LPG are the preferable fuels for CHP systems while in rural communities biogas, produced locally by digestion of organic matter, could be used. Due to the high overall energy efficiency, in the range of $80 \%-90 \%$, CHP systems are environmentally friendly and cost-effective covering all the energy requirements in large "industrial greenhouses". However their high installation cost does not favor their use in small size "Mediterranean-type greenhouses". Commercial use of fuel cells in greenhouses, according to my best knowledge, has not been reported so far.

\subsection{Electricity generation by solar-PVs}

Solar-PV panels on-site can be used for electricity generation in small- or large-size greenhouses, taking into account their space availability. The opaque or semi-transparent solar panels, generating electricity, can be installed on the greenhouse's rooftop, nearby them or they can be mobile. Off-site installation of solar panels is allowed in many countries according to virtual net-metering regulations. Generated electricity depends on the surface and efficiency of the solar panels, the solar irradiance and the overall efficiency of the system according to the equation:

$\mathrm{E}=\mathrm{AX}$ r X H X e (1) where

$\mathrm{E}=$ generated electricity in $\mathrm{KWh}$ per year,

$\mathrm{A}=$ surface of the panel in $\mathrm{m}^{2}$,

$\mathrm{r}=\mathrm{PV}$-panel's efficiency, dimensionless,

$\mathrm{H}=$ annual solar radiation on proper inclination in $\mathrm{KWh}$ per $\mathrm{m}^{2}$, and

$\mathrm{e}=$ overall efficiency of the system, dimensionless.

\subsection{Electricity generation by wind turbines}

Greenhouses in Crete are mostly located in areas with rich wind energy resources. Therefore wind turbines could be installed, either on-site or off-site, in the greenhouse generating electricity. Part of the generated electricity can be selfconsumed while the rest can be sold into the grid. However various barriers exist including the time-consuming requirements for obtaining the necessary licenses for wind turbines' installation in Crete, discouraging potential investors. The characteristics of various electricity generation systems which are used or could be used in greenhouses are presented in Table 2. 
Table 2. Characteristics of various electricity generation systems for greenhouses

\begin{tabular}{|c|c|}
\hline Electricity generation system & Characteristics \\
\hline CHP & $\begin{array}{l}\text { High initial investment } \\
\text { Very high overall energy efficiency } \\
\text { The system can cover all the heat and power requirements in } \\
\text { the greenhouse, selling the surplus electricity into the grid } \\
\text { It is currently used in modern industrial greenhouses } \\
\text { The system is usually fuelled by natural gas }\end{array}$ \\
\hline Fuel cell & $\begin{array}{l}\text { High initial investment } \\
\text { High energy efficiency } \\
\text { The system can cover all the heat and power requirements in } \\
\text { the greenhouse, selling the surplus electricity into the grid } \\
\text { It is not used in commercial greenhouses } \\
\text { It is fuelled by natural gas }\end{array}$ \\
\hline Solar-PV & $\begin{array}{l}\text { High initial investment } \\
\text { The fuel is free } \\
\text { Low energy efficiency } \\
\text { It generates only electricity } \\
\text { It has limited commercial use so far while it can be used in } \\
\text { small- or large-size greenhouses } \\
\text { It is suggested in areas with high solar irradiance }\end{array}$ \\
\hline Wind turbine & $\begin{array}{l}\text { High initial investments } \\
\text { It generates only electricity } \\
\text { It is suggested in areas with high wind potential } \\
\text { The fuel is free }\end{array}$ \\
\hline
\end{tabular}

\section{Possibilities of installing solar-PV panels in greenhouses in Crete}

\subsection{Estimation of solar electricity generation in greenhouses in Crete}

A case study regarding electricity generation with semi-transparent PVs installed on the rooftop in agricultural greenhouses in Crete has been realized under the following assumptions:

a) Semi-transparent crystalline silicon modules will be installed with $30-40 \%$ transparency,

b) The area of the greenhouse is 10 ha while $15 \%$ of its rooftop $\left(15,000 \mathrm{~m}^{2}\right)$ will be covered with semi-transparent solarPVs,

c) The annual electricity generation from the solar panels will be $1,400 \mathrm{KWh} / \mathrm{KW}_{\mathrm{p}}$,

d) The nominal power per unit surface of the semi-transparent solar panels is $80 \mathrm{~W} / \mathrm{m}^{2}$,

e) The installation cost of the solar panels is estimated at $2 € / \mathrm{W}_{\mathrm{p}}$, and

f) The life time of the solar system is 25 years, its annual maintenance cost is $1 \%$ of its installation cost, while the generated electricity is reduced annually during its life time, by $1 \%$.

The nominal power of the installed solar panels, in a surface at $15,000 \mathrm{~m}^{2}$, is $1,200 \mathrm{KW}_{\mathrm{p}}$, the initial annual electricity generation from the solar panels is calculated at $1,680,000 \mathrm{KWh}$ while the investment cost is at 2,400,000€ or $24 €$ per $\mathrm{m}^{2}$ of the greenhouse surface.

The levelized cost of electricity (L.C.O.E.) is estimated as the ratio of the sum of costs over the life time divided by the total electricity generated over the life time.

L.C.O.E. $=($ sum of costs incurred over life time $) /($ sum of electricity generated over life time $)(2)$

The L.C.O.E. of the solar system is estimated from equation 2 at $0.082 € / \mathrm{KWh}$. This is lower than the current price of electricity at $0.11058 € / \mathrm{KWh}$ to $0.12269 € / \mathrm{KWh}$ provided from the national power company which is the largest power utility in Greece.

In order to estimate the greenhouse's total income from the co-produced crop and electricity, it is assumed that the annual revenues from the crop are $10 € / \mathrm{m}^{2}$ while the income due to electricity generation is $0.12 € / \mathrm{KWh}$. Since the annual electricity generation in the greenhouse has been estimated at $16.8 \mathrm{KWh} / \mathrm{m}^{2}$ the energy's annual revenues are estimated at $2.02 € / \mathrm{m}^{2}$ which correspond to $20 \%$ of the crops' revenues. Therefore, by installing solar-PVs in his greenhouse, the farmer obtains an increase in annual revenues which are now generated from two different sources.

\subsection{Environmental assessment of solar electricity generation in greenhouses in Crete}


Solar electricity generation in the above-mentioned greenhouse results in the reduction of carbon emissions attributed to grid electricity use. Electricity is currently generated in Crete in power stations using heating and diesel oil,as well as renewable energies, mainly solar and wind energy. Assuming that carbon emissions due to electricity use in Crete are $0.6 \mathrm{kgCO}_{2} / \mathrm{KWh}$, the annual generation of $1,680,000 \mathrm{KWh}$ by the solar-PV system installed in the greenhouse could decrease the annual carbon emissions by $1,008 \mathrm{tnCO}_{2}$, which corresponds to $10.08 \mathrm{kgCO}_{2}$ per $\mathrm{m}^{2}$ of the greenhouse's surface.

The characteristics of the semi-transparent solar-PV system which has been analyzed in the case study are presented in Table 3.

Table 3. Characteristics of the semi-transparent solar-PV system installed on the rooftop of the abovementioned greenhouse

\begin{tabular}{|c|c|}
\hline Area of the greenhouse & 10 ha \\
\hline $\begin{array}{l}\text { Surface of the semi-transparent solar-PVs } \\
\text { installed in the rooftop of the greenhouse }\end{array}$ & $15,000 \mathrm{~m}^{2}$ \\
\hline Nominal power of the solar panels & $80 \mathrm{~W}_{\mathrm{p}} / \mathrm{m}^{2}$ \\
\hline Nominal power of the solar-PV system & $1,200 \mathrm{KW}_{\mathrm{p}}$ \\
\hline $\begin{array}{l}\text { Annual specific electricity generation of the } \\
\text { solar panels }\end{array}$ & $1,400 \mathrm{KWh} / \mathrm{KW}_{\mathrm{p}}$ \\
\hline $\begin{array}{l}\text { Annual electricity generation of the solar-PV } \\
\text { system }\end{array}$ & $1,680,000 \mathrm{KWh}$ \\
\hline $\begin{array}{l}\text { Annual electricity generation per } \mathrm{m}^{2} \text { of the } \\
\text { greenhouse surface }\end{array}$ & $16.8 \mathrm{KWh} / \mathrm{m}^{2}$ \\
\hline Unit installation cost of the solar panels & $2,000 € / \mathrm{KW}_{\mathrm{p}}$ \\
\hline Installation cost of the solar-PV system & $2,400,000 €$ \\
\hline Investment cost per unit area of the greenhouse & $24 €$ per $\mathrm{m}^{2}$ \\
\hline Levelized cost of generated electricity & $0.082 € / \mathrm{KWh}$ \\
\hline Annual carbon emissions savings & $1,008 \mathrm{tnCO}_{2}$ \\
\hline $\begin{array}{l}\text { Annual carbon emissions savings } \\
\text { greenhouse surface }\end{array}$ & $10.08 \mathrm{kgCO}_{2} / \mathrm{m}^{2}$ \\
\hline
\end{tabular}

6. Creation of RES cooperatives among greenhouse owners generating electricity with solar-PV panels in Crete

Agricultural greenhouses with vegetable crops in Crete are located in specific areas with favorable climate conditions and high solar irradiance. Farmers in these locations have created agricultural cooperatives which support and assist them during vegetable cultivation as well as in standardizing and distributing their products in the markets. Additionally to the agricultural cooperatives, greenhouse growers could establish energy cooperatives which could assist them in installing solar-PV systems in their greenhouses, generating electricity and offering an additional income. Electricity generation in greenhouses will allow farmers to become not only energy consumers but also energy producers called "procumers". Experts employed in these cooperatives could assist them in achieving better energy management in their greenhouses and probably using other local renewable energy resources for producing green energy in their territories. Greek government is offering incentives for the creation of energy cooperatives while netmetering regulations allow the selling of the surplus electricity into the electric grid. Solar-PV investments are currently cost-effective due to the attractive solar irradiance in Crete which is particularly high in the specific areas with high concentration of greenhouses. Therefore the creation of energy cooperatives by greenhouse farmers will offer them an additional income while it will contribute in the decrease of fossil fuels use and carbon emissions due to energy use in agriculture. Additionally, they will promote the energy autonomy of greenhouse owners.

\section{Discussion}

Among different available technologies generating electricity in greenhouses the most promising for the "Mediterranean-type greenhouse" used in Crete is the solar-PV system. Our results indicated that the use of semitransparent solar-PVs in Cretan "Mediterranean-type greenhouses" covering a small part of their rooftop could generate electricity, offering the possibility to growers to co-produce vegetables and electricity. The generated energy could cover part or all of their electricity requirements while any surplus energy could be fed into the grid offering an additional, to the crop, income to the farmer. However it is not clear from the published literature under which circumstances the semi-transparent solar panels installed on the rooftop will not negatively affect the growth and the yields of the cultivated crops. Installation of semi-transparent solar panels in greenhouses is currently cost-effective 
while the annual revenues due to electricity generation are not negligible. It should be noted that the installation of solar panels on the rooftop of greenhouses should not decrease significantly with their shading, the incoming solar irradiance or alteration of the indoor microclimate. Otherwise the growth and yields of the cultivated crops could be negatively affected. Since, to my best knowledge, there are no experimental data reported so far in Greece regarding the use of semi-transparent solar panels on the rooftops of greenhouses, it is necessary to construct and operate an experimental system in order to investigate their impacts on plant growth.

\section{Conclusions}

Sustainable energy technologies which are currently used in agricultural greenhouses include: a) CHP systems generating heat and power already used in large industrial greenhouses, and b) Solar-PV systems generating electricity which have limited use in them so far. Technologies which could be used in the future include: a) Fuel cells generating heat and power, and b) Wind turbines generating electricity. Opaque or semi-transparent solar-PVs, installed in greenhouses, covering their electricity requirements and selling the surplus energy into the grid are profitable since their L.C.O.E. is at $0.082 € / \mathrm{KWh}$ is lower than the current price of grid electricity in Crete, while their use results in an additional revenue for the farmers. Installation of semi-transparent solar panels with a surface of $15,000 \mathrm{~m}^{2}$, covering $15 \%$ of the rooftop in a 10 ha greenhouse, results in annual electricity generation at $16.8 \mathrm{KWh}^{2}$ per $\mathrm{m}^{2}$ of greenhouse surface, and an annual decrease of $\mathrm{CO}_{2}$ emissions at $10.08 \mathrm{kgCO}_{2}$ per $\mathrm{m}^{2}$ of greenhouse surface, while the panel's installation cost is $24 €$ per $\mathrm{m}^{2}$ of greenhouse surface. The favorable Greek legislation and incentives towards the creation of energy communities combined with the high solar irradiance in Crete offers the opportunity for the creation of energy cooperatives in areas with high greenhouse concentration from farmers who already have established agricultural cooperatives. This will offer to them additional economic benefits, exploiting a local renewable energy source and differentiating their income, co-producing both food products and electricity in their greenhouses. Future research should be oriented towards the experimental investigation of the use of semi-transparent solar panels placed on the rooftops of greenhouses in Crete. The impacts of different roof coverage in greenhouses with semi-transparent solar panels for shading and altering the indoor environment should be investigated since they might affect the growth and yield of various crops.

\section{References}

Aroca-Delgado, R., Perez-Alonso, J., Callejon-Ferre, A.J. \& Velazquez-Martu, B. (2018). Compatibility between crops and solar panels: An overwiew from shading systems, Sustainability, 10, 743. doi:10.3390/su10030743

Canakci, M. \& Akinci, I. (2006). Energy use pattern analysis of greenhouse vegetable production, Energy, 31, 12431256. doi:10.1016/j.energy.2005.05.021

Castellano, S. (2014). Photovoltaic greenhouses: evaluation of shading effect and its influence on agricultural performances, Journal of Agricultural Engineering, XLV:433, 168-175.

Colantoni, A., Monarca, D., Marruci, A., Cecchini, M., Zambon, I., Di Battista, F., Maccario, D. Grazia Saporito, M. \& Beruto, M. (2018). Solar radiation distribution inside a greenhouse prototypal with photovoltaic mobile plant and effects on flower growth, Sustainability, 10, 855 doi:10.3390/su10030855

Combined heat and power generation at greenhouses, Discussion paper and standards, 2013. Ministry of Agriculture, British Columbia, Canada. Retrieved at 17/2/2020 from https://www2.gov.bc.ca/assets/gov/farming-naturalresources-and-industry/agriculture-and-seafood/agricultural-land-and-environment/strengthening-

farming/local-government-bylaw-standards/combined-heat-and-power-generation/chp_discussion_paper__may_2013.pdf

Compernolle, T., Witters, N., Van Passel, S. \& Thewys, Th. (2011). Analyzing a self-managed CHP system for greenhouse cultivation as a profitable way to reduce $\mathrm{CO}_{2}$-emissions, Energy, 36, 1940-1947. doi:10.1016/j.energy.2010.02.045

Cossu, M., Murgia, L., Ledda, L., Deligios, P.A., Sirigu, A. \& Chessa, F. (2014). Solar radiation distribution inside a greenhouse with south-oriented photovoltaic roofs and effects on crop productivity, Applied Energy, 133, 89100. http://dx.doi.org/10.1016/j.apenergy.2014.07.070

Cossu, M., Yano, A., Murgia, L., Ledda, L., Deligios, P.A., Sirigu, A., Chessa, F. \& Pazzona, A. (2017). Effects of photovoltaic roofs on the greenhouse microclimate, Acta Horticultura, 1170, 461-468. DOI 10.17660/ActaHortic.2017.1170.57

Creupelandt, D. \& Vansintjan, D. (2014). REScoop - Mobilizing European citizens to invest in sustainable energy, H2020 project REScoop MECISE, retrieved at 21/2/2020 from https://uploads.strikinglycdn.com/files/6054401a-6d2d-41b0-b575-80dfe 7b3c42d/REScoop\%20MECISE\%20\%20REScoop\%20-\%20Municipality\%20Approach.pdf 
Hassanien Reda Hassanien, E., Ming, L. \& Wei Dong, L. (2016). Advanced applications of solar energy in agricultural greenhouses, Renewable and Sustainable Energy Reviews, 54, 989-1001. http://dx.doi.org/10.1016/j.rser.2015.10.095

Hassanien Reda Hassanien, E. \& Ming, L. (2017). Influences of greenhouse-itegrated semi-transparent photovoltaics on microclimate and lettuce growth, International Journal of Agricultural and Biological Engineering, 10(6), 11-22. DOI: $10.25165 / j$. ijabe.20171006.3407

Kadowaki, M., Yano, A., Ishizu, F., Tanaka, T. \& Noda, S. (2012). Effects of greenhouse photovoltaic array shading on Welsh onion growth, Biosystems Engineering, 111, 290-297. doi:10.1016/j.biosystemseng.2011.12.006

Kagarakis, K. (1987). Photovoltaic Technology, Symetria publications, Athens, Greece (In Greek).

Li, Z., Yano, A., Cossu, M., Yoshioka, H., Kita, I. \& Ibaraki, Y. (2018). Electrical energy producing greenhouse shading system with a semi-transparent photovoltaic blind based on micro-spherical solar cells, Energies, 11, 1681. doi:10.3390/en11071681

Marucci, A., Gusman, A., Pagnielle, B. \& Cappuccini, A. (2013). Limits and prospects of photovoltaic covers in Mediterranean greenhouses, Journal of Agricultural Engineering, 44(1). https://doi.org/10.4081/jae.2013.e1

Martellota, F., Cannavale, A. \& Ayr, U. (2017). Comparing energy performance of different semi-transparent, building-integrated photovoltaic cells applied to "reference" buildings, Energy Procedia, 126, 219-226. 10.1016/j.egypro.2017.08.143

Moretti, S. \& Marucci, A. (2019). A photovoltaic greenhouse with variable shading for the optimization of agricultural and energy production, Energies, 12, 2589. doi:10.3390/en12132589

Reiner van der Veen, A.C. \& Kasmire, J. (2015). Combined heat and power in Dutch greenhouses: A case study of technology diffusion, Energy Policy, 87, 8-16. http://dx.doi.org/10.1016/j.enpol.2015.08.040

Sardella, M. (2013). Energy analysis of a fuel cell system for commercial greenhouse applications, M.Sc. Thesis at KTH School of Industrial Engineering and Management, Stockholm, Sweden. Retrieved at 20/2/2020 from https://pdfs.semanticscholar.org/7719/992b5e466d6ecca9f5f076d4b69fae05bfdf.pdf?_ga=2.170451488.18818 85740.1582569228-1860547027.1582569228

Tataraki, K.G., Kavvadias, K.C. \& Maroulis, Z.B. (2019). Combined cooling heating and power systems in greenhouses. Grassroots and retrofit design, Energy, 189, 116-283. https://doi.org/10.1016/j.energy.2019.116283

Urena-Sanchez, R., Callejon-Ferre, A.J., Perez-Alanso, J. \& Carreno-Ortega, A. (2012). Greenhouse tomato production with electricity generation by roof-mounted flexible solar panels, Scientia Agricola, 69(4), 233-239.

Villarroel-Schneider, J. Malmuquist, A., Araoz, J.A., Marti-Herrero, J. \& Martin, A. (2019). Performance analysis of a small-scale biogas based tri-generation plant: An absorption refrigeration system integrated to an external fired micro-turbine, Energies, 12, 3830. doi:10.3390/en12203830

Vourdoubas, J. (2016). Possibilities of using semi-transparent photovoltaic modules on rooftops of greenhouses for covering their energy needs, Journal of Agricultural Studies, 4(1), 90-100. DOI: 10.5296/jas.v4i1.8694

Vourdoubas, J. (2018). Economic assessment of solar photovoltaics use in agricultural greenhouses in Greece, Journal of Agricultural Studies, 6(4), 23-35. DOI: 10.5296/jas.v6i4.13896

Xue, J. (2017). Economic assessment of photovoltaic greenhouses in hina, Journal of Renewable and Sustainable Energy, 9, 033502. doi: 10.1063/1.4982748

Yano, A., Furue, A., Kadowaki, M., Tanaka, T., Hiraki, E., Miyamoto, M., Ishizu, F. \& Noda, S. (2009). Electrical energy generated by photovoltaic modulus mounted inside the roof of a north-south oriented greenhouse, Biosystems Engineering, 103, 228-238. doi:10.1016/j.biosystemseng.2009.02.020

Yano, A., Onoe, M. \& Nakata, J. (2014). Prototype semi-transparent photovoltaic modules for greenhouse roof applications, Biosystems Engineering, 122, 62-73. http://dx.doi.org/10.1016/j.biosystemseng.2014.04.003 